Marquette University

e-Publications@Marquette

School of Dentistry Faculty Research and

Publications

Dentistry, School of

$1-1-2017$

\title{
The Relationships Between Fluoride Intake Levels and Fluorosis of Late-Erupting Permanent Teeth
}

Pradeep Bhagavatula

Marquette University, pradeep.bhagavatula@mu.edu

Alexandra Curtis

University of Iowa

Barbara Broffitt

University of Iowa

Karin Weber-Gasparoni

University of Iowa

John J. Warren

University of Iowa

See next page for additional authors

Accepted version. Journal of Public Health Dentistry (2017). DOI. (C) 2017 John Wiley \& Sons, Inc. Used with permission. 
Authors

Pradeep Bhagavatula, Alexandra Curtis, Barbara Broffitt, Karin Weber-Gasparoni, John J. Warren, and Steven M. Levy 
Marquette University

e-Publications@Marquette

\section{Dentistry Faculty Research and Publications/College of Dentistry}

This paper is NOT THE PUBLISHED VERSION; but the author's final, peer-reviewed manuscript. The published version may be accessed by following the link in th citation below.

Journal of Public Health Dentistry, Vol. 78, No. 2 (Spring 2018): 165-174. DOI. This article is (C) Wiley and permission has been granted for this version to appear in e-Publications@Marquette. Wiley does not grant permission for this article to be further copied/distributed or hosted elsewhere without the express permission from Wiley.

\section{The Relationships Between Fluoride Intake Levels and Fluorosis of Late-Erupting Permanent Teeth}

\section{Pradeep Bhagavatula}

Department of Clinical Services, Marquette University School of Dentistry, Milwaukee, WI Alexandra Curtis Department of Biostatistics, College of Public Health, University of lowa, lowa City, IA Barbara Broffitt Department of Preventive \& Community Dentistry, College of Dentistry, University of lowa, lowa City, IA Karin Weber-Gasparoni

Department of Pediatric Dentistry, College of Dentistry, University of lowa, lowa City, IA, John Warren

Department of Preventive \& Community Dentistry, College of Dentistry, University of lowa, lowa City, IA Steven M. Levy

Department of Preventive \& Community Dentistry, College of Dentistry, University of lowa, lowa City, IA Department of Epidemiology, College of Public Health, University of lowa, lowa City, IA 


\section{Abstract}

\section{Objectives}

To examine the relationships between fluoride intake levels and fluorosis of late-erupting permanent teeth.

\section{Methods}

The current study used information collected from 437 children in the longitudinal lowa Fluoride Study. Participants' fluoride intake information was collected using questionnaires from birth to age 10 years. Estimated mean daily fluoride intake was categorized into low, moderate, and high intake tertiles for each age interval (2-5, 5-8, and 2-8 years). Bivariate analyses were performed to study the relationships between selfreported fluoride intake levels during three age intervals and dental fluorosis.

Results

For canines and second molars, the prevalence of mostly mild fluorosis was less than $10 \%$ in the lowest fluoride intake tertile and more than $25 \%$ in the highest intake tertile. For both first and second premolars, the prevalence in the low and high intake tertiles was approximately $10-15 \%$ and $25-40 \%$, respectively. When estimated total daily fluoride intake was $0.04 \mathrm{mg} / \mathrm{kg}$ BW during ages 2-8 years, the predicted probability of fluorosis was $16.0 \%, 20.5 \%, 21.8 \%$, and $15.4 \%$ for canines, 1 st and 2 nd and premolars and 2 nd molars, respectively. We found that an incremental increase in fluoride intake during the age 5- to 8-year interval led to greater odds for development of mostly mild dental fluorosis in late-erupting teeth compared to increases in fluoride intake during other age intervals.

\section{Conclusions}

Our results clearly show that dental fluorosis prevalence is closely related to fluoride intake levels and that teeth have greater susceptibility to fluoride intake during certain age intervals.

\section{Introduction}

Dental caries is one of the most prevalent human diseases globally. However, over the past few decades, dental caries rates have declined significantly in most developed countries. This decline is attributed largely to increased availability and use of fluorides $\underline{\mathbf{1}}-\underline{\mathbf{4}}$. In the past, the caries preventive benefits of fluoride were thought to be primarily due to the incorporation of fluoride into the developing enamel crystal, reducing the acid solubility of enamel $\underline{\mathbf{5}} \underline{\mathbf{6}}$. Some recent studies conducted in Australia have also reported that pre-eruptive exposure to fluoride plays an important role in prevention of dental caries $\underline{7}$. However, most researchers currently believe that the primary mechanisms by which fluoride prevents dental caries are by topical action. Fluoride acts by inhibiting loss of mineral from the tooth (demineralization) and by promoting remineralization (uptake of calcium and phosphate). At high concentrations, fluoride also can affect bacterial metabolism and thereby inhibit dental caries.

The increased availability and use of fluorides has led to an increase in the prevalence of mostly mild dental fluorosis in the United States $\underline{4}$. Consuming greater than optimal amounts of fluoride during critical periods of tooth development can lead to an increase in subsurface enamel porosity that causes the clinical presentation of dental fluorosis $\underline{\mathbf{8}}$. The clinical presentation of dental fluorosis ranges from almost imperceptible white lacy striations in milder forms to brownish discoloration and/or confluent pitting in severe cases $\underline{8}$.

Quantity, frequency, and timing of fluoride intake are important determinants of dental fluorosis $\underline{\mathbf{9}} \underline{\mathbf{1 4}}$. Only developing teeth are susceptible to fluorosis and teeth are more susceptible to fluorosis during certain stages of development than others $\underline{\mathbf{8}}, \underline{\mathbf{1 0}}, \underline{\mathbf{1 1}}$. Previous analyses from the lowa Fluoride Study (IFS) have found that the late-erupting permanent teeth (canines, premolars, and second molars) are at risk up to the age of 8 years $\underline{10}, \underline{11}$. Similar time periods were described by other investigators who examined the risk periods for dental fluorosis on late-erupting permanent teeth (which erupt mostly at ages 9-11). At sufficiently high fluoride 
intake levels, teeth are susceptible to fluorosis during all stages of development $\underline{\mathbf{8}}, \underline{\mathbf{9}}, \underline{\mathbf{1 5}}$. The prevalence and severity of fluorosis increase in a dose-dependent manner with greater fluoride intake $\underline{\mathbf{2}}, \underline{\mathbf{8}} \underline{\mathbf{9}} \underline{\mathbf{1 6}}, \underline{\mathbf{1 7}}$.

Several studies have examined the patterns of fluoride intake and their relation to development of dental fluorosis, as well as with dental caries experience among young children. The results from these studies are summarized in Table $\underline{1}$.

Table 1. Estimated Mean Daily Fluoride Intake Values from Previous Studies and Review Articles

\begin{tabular}{|c|c|c|c|c|}
\hline Report/first author & $\begin{array}{l}\text { Country/region of } \\
\text { study }\end{array}$ & $\begin{array}{l}\text { Fluoride intake } \\
\text { sources assessed }\end{array}$ & $\begin{array}{l}\text { Age range of } \\
\text { children }\end{array}$ & $\begin{array}{l}\text { Average daily fluoride } \\
\text { intake in milligrams } \\
\text { fluoride per kilogram } \\
\text { body weight (mg F/kg } \\
\text { BW-day)- unless } \\
\text { specified }\end{array}$ \\
\hline \multicolumn{5}{|l|}{ Mean fluoride intake } \\
\hline McClure $\underline{29}$ & United States & Drinking water & $1-12$ years & $0.05-0.07$ \\
\hline Levy et al. $\underline{25}$ & $\begin{array}{l}\text { United States } \\
\text { (lowa) }\end{array}$ & $\begin{array}{l}\text { Dietary and nondietary } \\
\text { sources* }\end{array}$ & $\begin{array}{l}0-3 \text { months } \\
6 \text { and } 9 \\
\text { months } \\
12 \text { and } 16 \\
\text { months } \\
20-36 \\
\text { months. }\end{array}$ & $\begin{array}{l}0.075 \\
0.060 \\
0.035 \\
0.043\end{array}$ \\
\hline Levy et al. $\underline{26}$ & $\begin{array}{l}\text { United States } \\
\text { (lowa) }\end{array}$ & $\begin{array}{l}\text { Dietary and nondietary } \\
\text { sources* }\end{array}$ & $36-72$ months & 0.05 \\
\hline Maguire et al. $\underline{30}$ & United Kingdom & Diet and toothpaste & $6-7$ years & $\begin{array}{l}\text { low-fluoride areas - } 0.031 \\
\text { sub-optimally - } 0.038 \\
\text { optimally fluoridated - } \\
0.047\end{array}$ \\
\hline Levy et al. $\underline{31}$ & $\begin{array}{l}\text { United States } \\
\text { (lowa) }\end{array}$ & $\begin{array}{l}\text { Dietary and nondietary } \\
\text { sources* }\end{array}$ & $6-9.5$ years & $\begin{array}{l}0.026 \text { for girls } \\
0.031 \text { for boys }\end{array}$ \\
\hline \multicolumn{5}{|l|}{$\begin{array}{l}\text { Threshold intake amounts } \\
\text { to avoid dental fluorosis }\end{array}$} \\
\hline Larsen et al. $\underline{17}$ & Denmark & Drinking water & $7-12$ years & 0.03 to 0.1 \\
\hline Manji et al. $\underline{21}$ & Kenya & Drinking water & 14-16-years & 0.03 \\
\hline $\begin{array}{l}\text { Whitford 32(Review } \\
\text { article) }\end{array}$ & - & $\begin{array}{l}\text { Dietary and nondietary } \\
\text { sources* }\end{array}$ & & $0.75-1.0 \mathrm{mg} /$ day \\
\hline Aasenden and Peebles $\underline{33}$ & $\begin{array}{l}\text { United States } \\
\text { (Massachusetts) }\end{array}$ & $\begin{array}{l}\text { Children living in non- } \\
\text { fluoridated } \\
\text { communities and } \\
\text { consuming fluoride } \\
\text { supplements }\end{array}$ & $\begin{array}{l}\text { Children and } \\
\text { adults }\end{array}$ & $\begin{array}{l}0.5 \mathrm{mg} / \text { day from Birth to } \\
3 \text { years } \\
1 \mathrm{mg} / \text { day in subsequent } \\
\text { years }\end{array}$ \\
\hline $\begin{array}{l}\text { United States Institute of } \\
\text { Medicine } \\
\text { recommendation } \underline{34}\end{array}$ & - & $\begin{array}{l}\text { Dietary and nondietary } \\
\text { sources* }\end{array}$ & $\begin{array}{l}\text { All age ranges } \\
\text { above } 6 \\
\text { months of } \\
\text { age }\end{array}$ & $\begin{array}{l}-0.05 \mathrm{mg} / \mathrm{kg} \text { BW/day } \\
\text { Upper limit of } 2.8 \mathrm{mg} \\
\text { F/day for 4- to } 8 \text {-year- } \\
\text { olds } \\
10 \mathrm{mg} \mathrm{F} / \text { day for children } \\
\text { and adults } 9 \text { years and } \\
\text { older. }\end{array}$ \\
\hline Hong et al. $\underline{9}$ & $\begin{array}{l}\text { United States } \\
\text { (lowa) }\end{array}$ & $\begin{array}{l}\text { Dietary and nondietary } \\
\text { sources* }\end{array}$ & $11-15$ years & 0.04 to 0.06 \\
\hline $\begin{array}{l}\text { Optimum intake amoun } \\
\text { to minimize fluorosis an }\end{array}$ & & & & \\
\hline
\end{tabular}




\begin{tabular}{|c|c|c|c|c|}
\hline $\begin{array}{l}\text { maximize caries } \\
\text { prevention }\end{array}$ & & & & \\
\hline McClure et al. $\underline{29}$ & & Drinking water & $1-12$ years & 0.05 to 0.07 \\
\hline Burt $\underline{1}$ & & $\begin{array}{l}\text { Dietary and nondietary } \\
\text { sources* }\end{array}$ & $\begin{array}{l}3 \text { years } \\
6-8 \text { years }\end{array}$ & $\begin{array}{l}0.04-0.05 \\
0.03-0.05\end{array}$ \\
\hline Warren et al. $\underline{35}$ & $\begin{array}{l}\text { United States } \\
\text { (lowa) }\end{array}$ & $\begin{array}{l}\text { Dietary and nondietary } \\
\text { sources* }\end{array}$ & $\begin{array}{l}9 \text { years with } \\
\text { no caries } \\
\text { history and } \\
\text { no fluorosis }\end{array}$ & $\begin{array}{l}\mathrm{F} \text { intake less than or } \\
\text { equal to } 0.05 \mathrm{mg} \mathrm{F} / \mathrm{kg} \\
\text { BW/day during the first } 4 \\
\text { years of life }\end{array}$ \\
\hline
\end{tabular}

- *Sources such as water, beverages, selected foods, dietary fluoride supplements, and fluoridated toothpaste.

The prevalence of dental fluorosis generally is higher among late-erupting permanent teeth as compared to the incisors 18-23. Additionally, the mesial surfaces of canines are esthetically prominent. However, very few studies have examined the relationships between period-specific fluoride intake from multiple sources and risk of dental fluorosis among the late-erupting teeth. Studies on fluorosis of late-erupting permanent teeth have focused on timing of fluoride intake as opposed to the actual amounts of fluoride intake $\underline{11-14}$. It is important to understand the relationship between contemporary fluoride intake levels and dental fluorosis of late-erupting teeth, as this can help guide fluoride use and intake recommendations. Assessing the relationships also can improve the understanding of the biologic mechanisms involved in dental fluorosis. This paper reports findings concerning the relationships between fluorosis on late-erupting permanent teeth and period-specific fluoride intakes from ages 2 to 8 years collected as part of the longitudinal lowa Fluoride Study.

\section{Methods}

These analyses used data for subjects who were participants in the IFS, a longitudinal study of a birth cohort. The IFS was approved by the University of lowa's Institutional Review Board. The study's methods were described in previous reports in greater detail 24-26. Briefly, during the years 1992-1995, a total of 1,882 mothers with newborn children were recruited from eight lowa hospital postpartum units to participate in the IFS. The mothers provided informed consent and completed baseline questionnaires. Later, the families were sent a series of surveys collecting information about the children's exposures to fluoride from dietary (water, beverages, selected food products, dietary fluoride supplements) and nondietary (fluoride toothpaste) sources during the preceding weeks. The questionnaires were sent mostly at 3-and 4-month intervals from birth to age 48 months, and then every 6 months thereafter. Children's combined daily fluoride intake from these sources in milligrams per kilogram bodyweight ( $\mathrm{mg} \mathrm{F} / \mathrm{kg} \mathrm{BW/day)} \mathrm{was} \mathrm{estimated} \mathrm{based} \mathrm{on} \mathrm{the} \mathrm{information} \mathrm{provided} \mathrm{by} \mathrm{the}$ parents in questionnaire responses and assays of children's drinking water, beverages, and selected foods.

\section{Fluoride intake assessment}

Fluoride intake measurements were not evenly spaced in time, hence trapezoidal area- under- the-curve (AUC) calculations $2 \mathbf{7}$ were used to determine the mean fluoride intake in $\mathrm{mg} \mathrm{F} / \mathrm{kg} \mathrm{BW} /$ day. The trapezoidal AUC measure provides a weighted average of fluoride intake. The weights are determined by how far apart in time the observations were recorded. AUCs were used to calculate the mean fluoride intakes for participants for age 2-5 years if subjects had a completed questionnaire returned before age 2 , between ages 2 and 5 , and after age 5. Similarly, AUC was calculated for subjects for ages 5-8 if they completed a questionnaire between ages 2 and 5 , between ages 5 and 8 , and after age 8. For those subjects with AUC determined for both 2-5 and 5-8 years, fluoride intake for the 6 -year period from 2 to 8 years was determined by averaging the two AUC calculations.

The estimated mean daily fluoride intakes were categorized into tertiles using data for participants who had both an age 13 fluorosis exam and enough questionnaires to allow for AUC calculations for both age ranges. When choosing cutoffs to categorize a continuous variable, there are two usual ways to proceed: a) Choose cutoffs which are clinically meaningful so as to further improve interpretability, or b) Choose cutoffs which place a similar number of subjects in each category, to improve statistical power. Previous analyses from the lowa 
Fluoride Study found that categorizing fluoride intake into tertiles provided clinically meaningful results as they found significant positive associations between fluorosis prevalence and increasing levels of fluoride intake $\underline{9}$. In order to improve interpretability of the results, we decided to categorize subjects by low, moderate, and high fluoride intakes for part of the analysis.

\section{Dental examinations}

The subjects underwent dental caries and fluorosis examinations at approximately ages 5, 9, 13, and 17 . These analyses use dental fluorosis findings from the age 13-year IFS exams (mean 13.5, range 12.4-16.0) which were performed by two trained and calibrated examiners using a portable dental chair, mouth mirror, and exam light 28. The examiners were blinded to the children's fluoride intake levels. A total of 550 subjects were examined for dental fluorosis on the 16 late-erupting permanent teeth (canines, 1st premolars, 2nd premolars, and 2nd molars) 28. All zones (incisal edge/occlusal table, occlusal third, middle third, and cervical third) of the buccal surfaces of the 16 late-erupting teeth (4 canines, 8 pre-molars, and 4 second molars) were assessed using the fluorosis risk index (FRI) $\underline{36}$. All zones were assigned FRI scores as follows: FRI Score $=0$ (no fluorosis), FRI Score $=1$ (questionable fluorosis when $<50$ percent of zone with white striations), FRI Score $=2$ (definitive fluorosis when $>50$ percent of zone with white striations), and FRI Score $=3$ (a surface zone has greater than 50 percent of the zone displaying pitting, staining, and deformity, indicative of severe fluorosis) $\mathbf{3 6}$. Dental fluorosis was defined as present for those having two or more teeth out of a tooth type (i.e., canines, 1st premolars, 2 nd premolars, 2nd molars) with definitive fluorosis (FRI scores of 2 or 3 on at least one zone). This analysis included scores from cervical zones of the 16 teeth only when the teeth were completely erupted. Fluorosis was distinguished from enamel demineralization ("white spot" lesions) based on color, texture, demarcation, and relationship with the gingival margin $\underline{\mathbf{3 7}}$, and from non-fluorosis opacities using Russell's criteria $\underline{\mathbf{3 8}}$, respectively.

Data analysis

Of the 550 participants with a fluorosis exam at age 13 , only 437 had returned an adequate number of questionnaires to provide fluoride intake information for both intake age periods ( $2-5$ and 5-8 years). Only these 437 children were included in this analysis. A case of dental fluorosis for a tooth type was defined as having definitive fluorosis (FRI Score 2 or 3 ) on at least two teeth of that particular tooth type. Subjects who had less than two teeth with definitive fluorosis and had at least one tooth with a missing fluorosis score for a particular tooth type or group were considered as indeterminate and excluded from analysis for that tooth type. Also, if a subject had no missing fluorosis scores and only one tooth in a tooth type with definitive fluorosis, they were excluded from the analysis for that tooth type. Fluorosis prevalence excluding subjects with insufficient questionnaire data and/or nondefinitive fluorosis is reported in Table $\underline{1}$.

We calculated the prevalence of dental fluorosis among subjects for each of the daily fluoride intake tertiles, as well as relative risk of fluorosis with corresponding 95 percent confidence intervals for the middle and upper tertiles compared to lower tertile for each age range and tooth type. We also examined trends in fluorosis prevalence for the subset of individuals who belonged to the same tertile of fluoride intake during both 3-year periods. We performed Cochran-Armitage tests to assess linear trends in the relationships among fluoride intake tertiles and dental fluorosis prevalence for each tooth type. We also examined the differences in fluorosis prevalence based on changes in fluoride intake tertiles over time by determining fluorosis prevalence for subjects cross-tabulating the ages 2-5 fluoride intake tertiles with the ages 5-8 tertiles.

Logistic regression curves predicting the probability of fluorosis prevalence for each tooth type were modeled using $\mathrm{mg} \mathrm{F/kg} \mathrm{BW}$ as the explanatory variable and are presented in Figure $\underline{1}$. For each tooth type, three different models were fit, using daily fluoride intake from ages 2-5, ages 5-8, and ages 2-8 as independent variables. Curves are shown for ranges of daily fluoride intake observed in the lowa Fluoride Study. Based on the regression models, we calculated the odds ratios for fluorosis risk and 95 percent confidence intervals for the odds ratio based on greater daily fluoride intake in increments of $0.01 \mathrm{mg} \mathrm{F} / \mathrm{kg} \mathrm{BW}$. Finally, we calculated the predicted probability of fluorosis prevalence for each tooth type based on the logistic regression models which 
used fluoride intake from ages 2 to 8 as the explanatory variable. All analyses were performed using SAS version 9.4 (SAS Institute Inc., Cary, NC, USA).
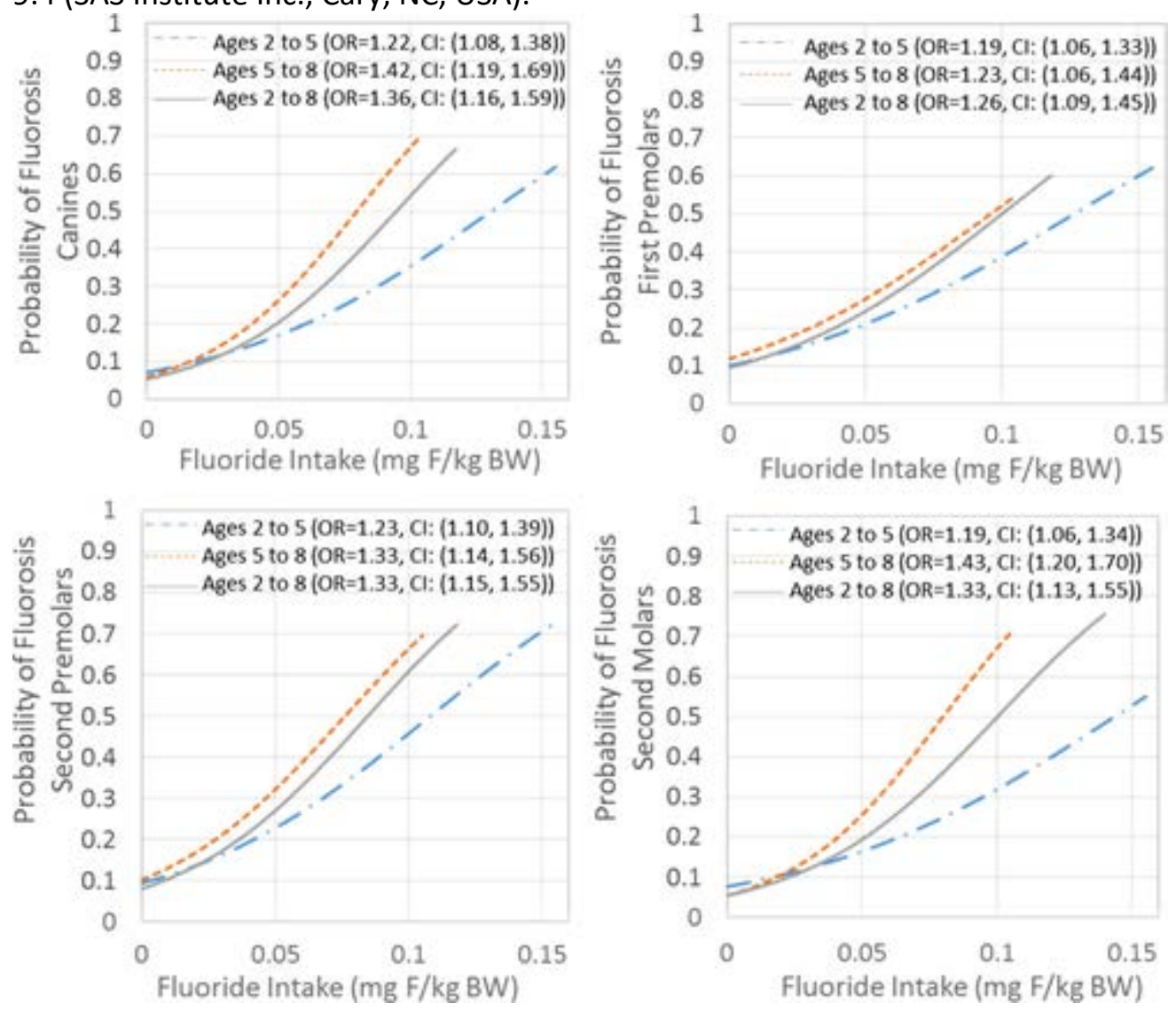

Figure 1 Logistic regression curves for each of the 4 tooth types. Odds ratios and 95 percent confidence intervals for 0.01 increment of $\mathrm{mg} \mathrm{F/kg} \mathrm{BW/day.} \mathrm{[Color} \mathrm{figure} \mathrm{can} \mathrm{be} \mathrm{viewed} \mathrm{at} \mathrm{wileyonlinelibrary.com]}$

\section{Results}

The mean age of the participants at the time of dental examinations was 13.5 years (median $=13.3$, range $=12.4-16.0$ ). A majority of the parents had a 2-year college degree or higher level of education (70 percent of mothers and 55 percent of fathers). The participants were predominantly non-Hispanic white (95 percent) and from middle to high income families (65 percent having annual family income of $\$ 60,000$ or more in 2007). Approximately 2.6 percent were white Hispanic, 1.5 percent were black or Native American. Asians and people with mixed race each constituted 1.0 percent of the study population.

The estimated mean daily fluoride intake ( $\mathrm{mg} \mathrm{F} / \mathrm{kg} \mathrm{BW}$ ) values were categorized into tertiles for each age interval. The tertiles for age 2-5 years were $<0.037 \mathrm{mg} \mathrm{F} / \mathrm{kg} \mathrm{BW}$ (low), 0.037-0.052 mg F/kg BW (moderate) and $>0.052 \mathrm{mg} \mathrm{F} / \mathrm{kg} \mathrm{BW}$ (high); for age 5-8 years, they were $<0.023 \mathrm{mg} \mathrm{F} / \mathrm{kg} \mathrm{BW}$ (low), 0.023-0.036 mg F/kg BW (moderate) and $>0.036 \mathrm{mg} \mathrm{F} / \mathrm{kg} \mathrm{BW}$ (high); and they were $<0.032 \mathrm{mgF} / \mathrm{kg} \mathrm{BW}$ (low), 0.032-0.044 mg F/kg BW (moderate)and $>0.044 \mathrm{mg} \mathrm{F} / \mathrm{kg} \mathrm{BW}$ (high) for age $2-8$ years.

Table $\underline{\mathbf{2}}$ presents the mean (standard deviation) numbers of fluoride intake questionnaire responses, estimated mean daily fluoride intakes, and fluorosis prevalence for subjects with determinate fluorosis scores and fluoride intake information available for both age categories. The number of children for whom both fluorosis scores and fluoride intake information was available varied by tooth type (canine $=269$, 1st premolar $=301$, 2nd premolar $=280$, and 2 nd molar $=251$ ). The mean $(S D)$ numbers of questionnaires returned were approximately 6.3 (2.1) for age 2-5 years, 5.0 (1.4) for age 5-8 years and 11.3 (3.0) for age 2-8 years. The mean (SD) overall daily 
fluoride intakes in $\mathrm{mg} \mathrm{F} / \mathrm{kg} \mathrm{BW}$ were approximately the same across subjects included in the analysis for each tooth type and were $0.05(0.02)$ for age $2-5$ years, $0.03(0.02)$ for age $5-8$ years and $0.04(0.02)$ for age $2-8$ years.

Table 2. Number of Responses, Daily Fluoride Intake, and Fluorosis Prevalence* for Subjects with Fluorosis Scores and Fluoride Intake Information Available for Both Age Ranges

\begin{tabular}{|l|l|l|l|l|}
\hline $\begin{array}{l}\text { Tooth type } \\
\text { present }\end{array}$ & $\begin{array}{l}\text { Fluoride intake age } \\
\text { ranges (years) }\end{array}$ & $\begin{array}{l}\text { Mean number of } \\
\text { responses‡(SD) }\end{array}$ & $\begin{array}{l}\text { Mean daily fluoride intake } \\
\text { in mg/day/Kg BW (SD) }\end{array}$ & $\begin{array}{l}\text { Fluorosis } \\
\text { prevalence-(\%) }\end{array}$ \\
\hline $\begin{array}{l}\text { Canines } \\
(n=269)\end{array}$ & $2-5$ & $6.3(2.1)$ & $0.05(0.02)$ & 17.8 \\
\hline & $5-8$ & $4.9(1.4)$ & $0.03(0.02)$ & \\
\hline $\begin{array}{l}\text { 1st Premolars } \\
(n=301)\end{array}$ & $2-8$ & $11.3(3.0)$ & $0.04(0.02)$ & 21.6 \\
\hline & $5-8$ & $6.3(2.2)$ & $0.05(0.02)$ & \\
\hline & $2-8$ & $5.0(1.4)$ & $0.03(0.02)$ & \\
\hline $\begin{array}{l}2 n d \text { Premolars } \\
(n=280)\end{array}$ & $2-5$ & $11.3(3.0)$ & $0.04(0.02)$ & \\
\hline & $5-8$ & $6.4(2.1)$ & $0.05(0.02)$ & \\
\hline & $2-8$ & $5.1(1.4)$ & $0.03(0.02)$ & \\
\hline $\begin{array}{l}2 n d \text { Molars } \\
(n=251)\end{array}$ & $2-5$ & $11.5(2.9)$ & $0.04(0.02)$ & \\
\hline & $5-8$ & $6.5(2.0)$ & $0.05(0.02)$ & \\
\hline & $2-8$ & $5.0(1.3)$ & $0.03(0.02)$ & \\
\hline
\end{tabular}

- *Fluorosis prevalence is defined as 2 or more teeth in a tooth group with definitive fluorosis using the Fluorosis Risk Index (FRI).

- This represents the mean number of questionnaire responses per subject per time period. Subjects received questionnaires every 3-4 months before age 4, and every 6 months after age 4 . For ages 2-5, the subjects received a maximum of 10 questionnaires, and for ages $5-8$, subjects received a maximum of 7 questionnaires.

The prevalence of dental fluorosis was low and most of the observed fluorosis was mild (FRI score $=2$ ). Very few children $(n=4)$ had an FRI score of 3 on two or more teeth which corresponds to moderate/severe dental fluorosis. After excluding subjects who were considered indeterminate for dental fluorosis, the overall (all lateerupting teeth) prevalence of fluorosis was 22.7 percent. The prevalence for individual tooth types was 17.8 percent for canines, 21.6 percent for 1st premolars, 23.6 percent for 2 nd premolars, and 17.1 percent for 2 nd molars.

Table $\underline{3}$ presents fluorosis prevalence stratified by the fluoride intake tertiles for the age intervals included in the analysis. The prevalence increased consistently for all tooth types and all age intervals with greater fluoride intake. For example, for canines, the fluorosis prevalence was 9.6, 16.1, and 26.9 percent for low, moderate, and high fluoride intake tertiles in the 2 - to 5 -year age interval, respectively. Table $\underline{\mathbf{2}}$ also reports the unadjusted relative risk (RR) values for fluorosis for the moderate and high fluoride intake tertiles compared to the low intake tertile. The one-sided $P$-values from Cochran-Armitage tests for linear trend among fluoride intakes during the three periods (2-5 years, 5-8 years, and 2-8 years) for specific tooth types also are shown in Table $\underline{\mathbf{3}}$. The " 2 intake age ranges steady" row includes subjects who were in the same fluoride intake tertile for both age intervals. The relative risks were generally significantly greater than 1 for children who had high fluoride intake, for all three age intervals and the steady intake groups for most tooth types. For first premolars, only fluoride intake for 2-5 years was significantly associated with increased risk of dental fluorosis. For children who had moderate levels of fluoride intake, the RR values were statistically significant only for the 2- to 8-year moderate intake tertile for canines, as well as the moderate intake tertile for ages 5-8, 2-8, and those with steady moderate intake during the two age ranges for second molars. Finally, all the $P$-values from Cochran-Armitage 
tests were statistically significant, indicating linear relationships between fluoride intake amounts and dental fluorosis prevalence.

Table 3. Fluorosis Prevalence* on Late-Erupting Teeth by Estimated Total Fluoride Intake Tertile

\begin{tabular}{|c|c|c|c|c|c|c|c|c|c|c|c|}
\hline & & & $\begin{array}{l}\text { Lo } \\
\text { w }\end{array}$ & & $\begin{array}{l}\text { Moderat } \\
\text { e }\end{array}$ & & & $\begin{array}{l}\text { Hig } \\
\mathrm{h}\end{array}$ & & & \\
\hline & $\begin{array}{l}\text { Fluorid } \\
\text { e } \\
\text { intake } \\
\text { age } \\
\text { ranges }\end{array}$ & $\begin{array}{l}\text { Subject } \\
\mathrm{s}\end{array}$ & $n$ & $\begin{array}{l}\% \\
\text { Fluoros } \\
\text { is }\end{array}$ & $n$ & $\begin{array}{l}\% \\
\text { Fluoros } \\
\text { is }\end{array}$ & $\begin{array}{l}\text { RR }(95 \% \\
\mathrm{Cl})\end{array}$ & $n$ & $\begin{array}{l}\% \\
\text { Fluoros } \\
\text { is }\end{array}$ & $\begin{array}{l}\text { RR }(95 \% \\
\mathrm{Cl})\end{array}$ & $\begin{array}{l}P \text { - } \\
\text { valuet }\end{array}$ \\
\hline \multirow[t]{4}{*}{ Canine } & $\begin{array}{l}2-5 \\
\text { Years }\end{array}$ & 269 & 83 & $9.6 \%$ & 93 & $16.1 \%$ & $\begin{array}{l}1.67 \\
(0.75 \\
3.74)\end{array}$ & 93 & $26.9 \%$ & $\begin{array}{l}2.79^{\ddagger}(1.3 \\
3,5.84)\end{array}$ & 0.0017 \\
\hline & $\begin{array}{l}5-8 \\
\text { Years }\end{array}$ & 269 & 86 & $9.3 \%$ & 87 & $13.8 \%$ & $\begin{array}{l}1.48 \\
(0.64, \\
3.45)\end{array}$ & 96 & $29.2 \%$ & $\begin{array}{l}3.14 \pm(1.5 \\
1,6.51)\end{array}$ & 0.0002 \\
\hline & $\begin{array}{l}2-8 \\
\text { Years }\end{array}$ & 269 & 89 & $6.7 \%$ & 86 & $20.9 \%$ & $\begin{array}{l}3.10^{ \pm}(1.2 \\
9,7.45)\end{array}$ & 94 & $25.5 \%$ & $\begin{array}{l}3.79^{ \pm}(1.6 \\
2,8.83)\end{array}$ & 0.0006 \\
\hline & $\begin{array}{l}2 \\
\text { Intake } \\
\text { Age } \\
\text { Ranges } \\
\text { Steady } \\
\mathbb{1}\end{array}$ & 167 & 55 & $9.1 \%$ & 47 & $17.0 \%$ & $\begin{array}{l}1.87 \\
(0.66, \\
5.34)\end{array}$ & 65 & $32.3 \%$ & $\begin{array}{l}3.55^{\ddagger}(1.4 \\
4,8.80)\end{array}$ & 0.0009 \\
\hline \multirow[t]{4}{*}{$\begin{array}{l}1 \text { st } \\
\text { Premola } \\
\text { rs }\end{array}$} & $\begin{array}{l}2-5 \\
\text { Years }\end{array}$ & 301 & 91 & $14.3 \%$ & 106 & $18.9 \%$ & $\begin{array}{l}1.32 \\
(0.70, \\
2.50)\end{array}$ & 104 & $30.8 \%$ & $\begin{array}{l}2.15 \pm(1.2 \\
1,3.85)\end{array}$ & 0.0030 \\
\hline & $\begin{array}{l}5-8 \\
\text { Years }\end{array}$ & 301 & 97 & $15.5 \%$ & 96 & $22.9 \%$ & $\begin{array}{l}1.48 \\
(0.82, \\
2.68)\end{array}$ & 108 & $25.9 \%$ & $\begin{array}{l}1.68 \\
(0.95 \\
2.95)\end{array}$ & 0.0426 \\
\hline & $\begin{array}{l}2-8 \\
\text { Years }\end{array}$ & 301 & 95 & $15.8 \%$ & 100 & $21.0 \%$ & $\begin{array}{l}1.33 \\
(0.73, \\
2.42)\end{array}$ & 106 & $27.4 \%$ & $\begin{array}{l}1.73 \\
(0.99 \\
3.03)\end{array}$ & 0.0280 \\
\hline & $\begin{array}{l}2 \\
\text { Intake } \\
\text { Age } \\
\text { Ranges } \\
\text { Steady } \\
\mathbb{1}\end{array}$ & 183 & 60 & $16.7 \%$ & 51 & $23.5 \%$ & $\begin{array}{l}1.41 \\
(0.67, \\
2.99)\end{array}$ & 72 & $31.9 \%$ & $\begin{array}{l}1.92 \\
(0.99, \\
3.70)\end{array}$ & 0.0261 \\
\hline \multirow[t]{4}{*}{$\begin{array}{l}\text { 2nd } \\
\text { Premola } \\
\text { rs }\end{array}$} & $\begin{array}{l}2-5 \\
\text { Years }\end{array}$ & 280 & 87 & $13.8 \%$ & 94 & $19.1 \%$ & $\begin{array}{l}1.39 \\
(0.71, \\
2.71)\end{array}$ & 99 & $36.4 \%$ & $\begin{array}{l}2.64^{\ddagger}(1.4 \\
7,4.74)\end{array}$ & 0.0001 \\
\hline & $\begin{array}{l}5-8 \\
\text { Years }\end{array}$ & 280 & 88 & $13.6 \%$ & 93 & $23.7 \%$ & $\begin{array}{l}1.73 \\
(0.91, \\
3.29)\end{array}$ & 99 & $32.3 \%$ & $\begin{array}{l}2.37^{\ddagger}(1.3 \\
0,4.31)\end{array}$ & 0.0017 \\
\hline & $\begin{array}{l}2-8 \\
\text { Years }\end{array}$ & 280 & 91 & $13.2 \%$ & 89 & $22.5 \%$ & $\begin{array}{l}1.70 \\
(0.89 \\
3.28)\end{array}$ & 100 & $34.0 \%$ & $\begin{array}{l}2.58^{\ddagger}(1.4 \\
2,4.67)\end{array}$ & 0.0004 \\
\hline & $\begin{array}{l}2 \\
\text { Intake } \\
\text { Age } \\
\text { Ranges } \\
\text { Steady } \\
\mathbb{1}\end{array}$ & 174 & 57 & $15.8 \%$ & 48 & $25.0 \%$ & $\begin{array}{l}1.58 \\
(0.73, \\
3.43)\end{array}$ & 69 & $40.6 \%$ & $\begin{array}{l}2.57 \pm(1.3 \\
2,4.99)\end{array}$ & 0.0012 \\
\hline
\end{tabular}




\begin{tabular}{|c|c|c|c|c|c|c|c|c|c|c|c|}
\hline $\begin{array}{l}\text { 2nd } \\
\text { Molars }\end{array}$ & $\begin{array}{l}2-5 \\
\text { Years }\end{array}$ & 251 & 80 & $6.3 \%$ & 78 & $15.4 \%$ & $\begin{array}{l}2.46 \\
(0.91 \\
6.66)\end{array}$ & 93 & $28.0 \%$ & $\begin{array}{l}4.47^{\ddagger}(1.8 \\
0,11.10)\end{array}$ & $\begin{array}{l}<0.000 \\
1\end{array}$ \\
\hline & $\begin{array}{l}5-8 \\
\text { Years }\end{array}$ & 251 & 87 & $5.7 \%$ & 76 & $19.7 \%$ & $\begin{array}{l}3.43^{\ddagger}(1.3 \\
1,9.01)\end{array}$ & 88 & $26.1 \%$ & $\begin{array}{l}4.55^{\ddagger}(1.8 \\
1,11.42)\end{array}$ & 0.0002 \\
\hline & $\begin{array}{l}2-8 \\
\text { Years }\end{array}$ & 251 & 89 & $6.7 \%$ & 71 & $18.3 \%$ & $\begin{array}{l}2.72 \pm(1.0 \\
9,6.79)\end{array}$ & 91 & $26.4 \%$ & $\begin{array}{l}3.91^{ \pm}(1.6 \\
8,9.11)\end{array}$ & 0.0003 \\
\hline & $\begin{array}{l}2 \\
\text { Intake } \\
\text { Age } \\
\text { Ranges } \\
\text { Steady } \\
\mathbb{I}\end{array}$ & 155 & 54 & $3.7 \%$ & 35 & $20.0 \%$ & $\begin{array}{l}5.40^{\ddagger}(1.1 \\
9,24.51)\end{array}$ & 66 & $30.3 \%$ & $\begin{array}{l}8.18^{ \pm}(2.0 \\
0,33.46)\end{array}$ & 0.0001 \\
\hline
\end{tabular}

- *Fluorosis prevalence is defined as two or more teeth in a tooth group with definitive fluorosis using Fluorosis Risk Index criteria. Subjects with only one tooth with definitive fluorosis were excluded from the analysis.

- $\quad+P$-value for Cochran-Armitage test for linear trend.

- $\quad ¥$ Relative risk and corresponding 95\% confidence interval entirely above 1 .

- $\quad$ IIncludes subjects who were in the same fluoride intake tertile for both age intervals.

The results examining the impact of sustained levels of fluoride intake on dental fluorosis prevalence during the age intervals $2-5$ and 5-8 years are presented in Table $\underline{4}$. We cross-tabulated fluorosis prevalence in the threefluoride intake tertiles for the 2-5 and 5- to 8-year age intervals. In each cell of Table $\underline{\mathbf{3}}$, the denominator represents the total number of subjects who were in the row and column tertiles of daily fluoride intake specified, while the numerator represents the number of these subjects who had fluorosis. The value in parentheses in each cell is the percentage given by the fraction in that cell. In general, the prevalence of fluorosis was low among subjects who had low fluoride intake for at least one of the age intervals and higher among individuals with high fluoride intake for at least one age interval. For example, for canines, the prevalence rates ranged from 5.0 to 25.0 percent for children with low daily fluoride intake during at least one of the age intervals and from 12.5 to 32.3 percent among those who had high intake during at least one interval. Subjects with high fluoride intake during both age intervals had higher fluorosis prevalence ( 32.3 percent) than those who had moderate intakes (17.0 percent) or low intake ( 9.1 percent) during both age intervals. The patterns of prevalence of fluorosis were less consistent among children who changed fluoride intake tertiles between different age intervals.

Table 4. Fluorosis Prevalence* by 2-5 Year and 5-8 Year Fluoride Intake Levels ${ }_{-}^{ \pm}$

\begin{tabular}{|c|c|c|c|c|c|c|c|c|c|}
\hline & $\begin{array}{l}\text { Age 5-8 } \\
\text { tertiles }\end{array}$ & & & & & $\begin{array}{l}\text { Age } 5-8 \\
\text { tertiles }\end{array}$ & & & \\
\hline & & Low & Moderate & High & Total & Low & Moderate & High & Total \\
\hline \multirow{4}{*}{$\begin{array}{l}\text { Ages 2- } \\
\mathbf{5} \\
\text { tertiles }\end{array}$} & Canines & & & & & $\begin{array}{l}\text { 1st } \\
\text { Premolar }\end{array}$ & & & \\
\hline & Low & $\begin{array}{l}5 / 55 \\
(9.1 \%)\end{array}$ & $\begin{array}{l}1 / 20 \\
(5.0 \%)\end{array}$ & $\begin{array}{l}2 / 8 \\
(25.0 \%)\end{array}$ & $\begin{array}{l}8 / 83 \\
(9.6 \%)\end{array}$ & $\begin{array}{l}10 / 60 \\
(16.7)\end{array}$ & $\begin{array}{l}2 / 23 \\
(8.7 \%)\end{array}$ & $\begin{array}{l}1 / 8 \\
(12.5 \%)\end{array}$ & $\begin{array}{l}13 / 91 \\
(14.3 \%)\end{array}$ \\
\hline & Moderate & $\begin{array}{l}2 / 23 \\
(8.7 \%)\end{array}$ & $\begin{array}{l}8 / 47 \\
(17.0 \%)\end{array}$ & $\begin{array}{l}5 / 23 \\
(21.7 \%)\end{array}$ & $\begin{array}{l}15 / 93 \\
(16.1 \%)\end{array}$ & $\begin{array}{l}4 / 27 \\
(14.8 \%)\end{array}$ & $\begin{array}{l}12 / 51 \\
(23.5)\end{array}$ & $\begin{array}{l}4 / 28 \\
(14.3 \%)\end{array}$ & $\begin{array}{l}20 / 106 \\
(18.9 \%)\end{array}$ \\
\hline & High & $\begin{array}{l}1 / 8 \\
(12.5 \%)\end{array}$ & $\begin{array}{l}3 / 20 \\
(15.0 \%)\end{array}$ & $\begin{array}{l}21 / 65 \\
(32.3 \%)\end{array}$ & $\begin{array}{l}25 / 93 \\
(26.9 \%)\end{array}$ & $\begin{array}{l}1 / 10 \\
(10.0 \%)\end{array}$ & $8 / 22(36.4)$ & $\begin{array}{l}23 / 72 \\
(31.9 \%)\end{array}$ & $\begin{array}{l}32 / 104 \\
(30.8 \%)\end{array}$ \\
\hline Total & & $\begin{array}{l}8 / 86 \\
(9.30 \%)\end{array}$ & $\begin{array}{l}12 / 87 \\
(13.9 \%)\end{array}$ & $\begin{array}{l}28 / 96 \\
(28.1 \%)\end{array}$ & $\begin{array}{l}48 / 269 \\
(17.8 \%)\end{array}$ & $\begin{array}{l}15 / 97 \\
(15.5 \%)\end{array}$ & $\begin{array}{l}22 / 96 \\
(22.9 \%)\end{array}$ & $\begin{array}{l}28 / 108 \\
(25.9 \%)\end{array}$ & $\begin{array}{l}65 / 301 \\
(21.5 \%)\end{array}$ \\
\hline $\begin{array}{l}\text { Ages 2- } \\
5 \\
\text { tertiles }\end{array}$ & $\begin{array}{l}\text { 2nd } \\
\text { Premolar }\end{array}$ & & & & & & 2nd Molar & & \\
\hline
\end{tabular}




\begin{tabular}{|l|l|l|l|l|l|l|l|l|l|}
\hline & Low & $9 / 57$ & $2 / 22$ & $1 / 8$ & $12 / 87$ & $2 / 54$ & $2 / 20(10.0)$ & $1 / 6$ & $5 / 80$ \\
& & $(15.8 \%)$ & $(9.1 \%)$ & $(12.5 \%)$ & $(13.8 \%)$ & $(3.7 \%)$ & & $(16.7 \%)$ & $(6.3 \%)$ \\
\hline & \multirow{2}{*}{ Moderate } & $3 / 24$ & $12 / 48$ & $3 / 22$ & $18 / 94$ & $3 / 27$ & $7 / 35(20.0)$ & $2 / 16$ & $12 / 78$ \\
& & $(12.5)$ & $(25.0 \%)$ & $(13.6 \%)$ & $(19.1 \%)$ & $(11.1 \%)$ & & $(12.5 \%)$ & $(15.4 \%)$ \\
\hline & High & $0 / 7$ & $8 / 23$ & $28 / 69$ & $36 / 99$ & $0 / 6$ & $6 / 21(28.6)$ & $20 / 66$ & $26 / 93$ \\
& & $(0.0)$ & $(34.8 \%)$ & $(40.6 \%)$ & $(36.4 \%)$ & $(0.0 \%)$ & & $(30.3 \%)$ & $(28.0 \%)$ \\
\hline Total & & $12 / 88$ & $22 / 93$ & $32 / 99$ & $66 / 280$ & $5 / 87$ & $15 / 76$ & $23 / 88$ & $43 / 251$ \\
& & $(13.6)$ & $(23.7 \%)$ & $(32.3 \%)$ & $(23.6 \%)$ & $(5.7 \%)$ & $(19.7)$ & $(26.1 \%)$ & $(17.1 \%)$ \\
\hline
\end{tabular}

- *Fluorosis prevalence is defined as two or more teeth in a tooth group with definitive fluorosis using Fluorosis Risk Index criteria.

- $\quad$ In each cell of Table $\underline{3}$, the denominator represents the total number of subjects who were in the row and column tertiles specified, while the numerator represents the number of subjects, out of those in the denominator, who had fluorosis prevalence. The value in parentheses in each cell is the percentage given by the fraction in that cell.

Results from separate logistic regression analyses predicting the probability of fluorosis for each tooth type using fluoride intake levels for the three age intervals are reported in Figure $\underline{1}$. Odds ratios are reported for a $0.01 \mathrm{mg} / \mathrm{kg} \mathrm{BW}$ increase in fluoride intake. All the odds ratios were statistically significantly greater than one. For example, for canines, the odds ratios and corresponding confidence intervals were $1.22(1.08,1.38), 1.42$ (1.19, 1.69), $1.36(1.16,1.59)$ for the ages $2-5,5-8$, and 2- to 8-year intervals, respectively (Figure 1 ). The odds ratios were consistently higher for fluoride intake during the ages 5- to 8-year interval than for ages 2-5. The predicted probability values also are higher for fluoride intake during the 5 - to 8 -year age interval than the other intervals that were examined (Figure $\underline{1}$ ).

In Table $\underline{5}$, we report the predicted probabilities of dental fluorosis based on the daily fluoride intake for the age interval from 2 to 8 years. At a daily fluoride intake level of $0.01 \mathrm{mg} / \mathrm{kg} \mathrm{BW}, 7.1,11.5,10.6$, and 7.2 percent of children would be expected to have definitive dental fluorosis on two or more canines, 1st and 2 nd and premolars and 2nd molars, respectively. The prevalence levels are estimated to be $61.7,55.7,67.6$, and 56.9 percent for canines, 1st and 2nd and premolars and 2nd molars, respectively, with fluoride intake of $0.11 \mathrm{mg} / \mathrm{kg}$ BW. The percentage increase in predicted fluorosis prevalence generally was greater at higher levels of fluoride intake. For example, for canines, when the daily fluoride intake increased from 0.01 to $0.02 \mathrm{mg} / \mathrm{kg} \mathrm{BW}$, the increase in prevalence was 2.3 percentage points (9.4-7.1 percent $=2.3$ percent), whereas when the fluoride intake increased from 0.10 to $0.11 \mathrm{mg} / \mathrm{kg}$ BW the increase was 7.4 percentage points $(61.7-54.3$ percent $=7.4$ percent).

Table 5. Predicted Probability of Fluorosis Prevalence* Based on Fluoride Intake (AUC) for Ages 2-8

\begin{tabular}{|l|l|l|l|l|}
\hline Intake for ages 2-8 (mg F/kg bw) & $\begin{array}{l}\text { Predicted } \\
\text { probability } \\
\text { of } \\
\text { fluorosis }\end{array}$ & & & \\
\hline & Canines & $\mathbf{1 s t}$ Premolars & 2nd Premolars & 2nd Molars \\
\hline 0.01 & $7.1 \%$ & $11.5 \%$ & $10.6 \%$ & $7.2 \%$ \\
\hline 0.02 & $9.4 \%$ & $14.1 \%$ & $13.6 \%$ & $9.4 \%$ \\
\hline 0.03 & $12.3 \%$ & $17.0 \%$ & $17.3 \%$ & $12.0 \%$ \\
\hline 0.04 & $16.0 \%$ & $20.5 \%$ & $21.8 \%$ & $15.4 \%$ \\
\hline 0.05 & $20.5 \%$ & $24.4 \%$ & $27.1 \%$ & $19.4 \%$ \\
\hline 0.06 & $25.9 \%$ & $28.8 \%$ & $33.2 \%$ & $24.3 \%$ \\
\hline 0.07 & $32.2 \%$ & $33.7 \%$ & $39.8 \%$ & $29.8 \%$ \\
\hline 0.09 & $39.2 \%$ & $38.9 \%$ & $46.9 \%$ & $36.1 \%$ \\
\hline 0.10 & $46.7 \%$ & $44.5 \%$ & $54.0 \%$ & $42.8 \%$ \\
\hline 0.11 & $54.3 \%$ & $50.1 \%$ & $61.0 \%$ & $49.8 \%$ \\
\hline & $61.7 \%$ & $55.7 \%$ & $67.6 \%$ & $56.9 \%$ \\
\hline
\end{tabular}


- *Fluorosis prevalence is defined as two or more teeth in a tooth group with definitive fluorosis.

\section{Discussion}

Current recommendations on fluoride intake are based mostly on studies conducted in the 1930s and 1940s,

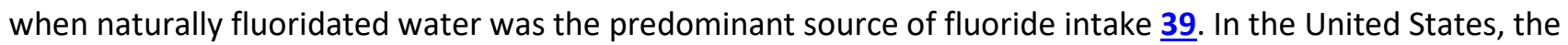
number of sources of fluoride has increased substantially and so has the prevalence of (mostly very mild and mild) dental fluorosis $\underline{1}, \underline{4}$. Previous studies on the relationship between fluoride-intake and fluorosis have focused mostly on individual fluoride intake sources from nonlongitudinal samples $\underline{12}, \underline{13}, \underline{17}, \underline{18}$. Hong et al. $\underline{9}$ examined the relationships between fluoride intake levels and dental fluorosis on early-erupting teeth using period-specific, longitudinal fluoride intake information from contemporary exposures.

The "optimal" daily fluoride intake range is considered to be $0.05-0.07 \mathrm{mg} \mathrm{F} / \mathrm{kg}$ BW $\underline{1}$. Different studies have suggested different fluoride intake threshold values for development of dental fluorosis. The results from these studies have been summarized in Table $\underline{1}$.

The current study categorized estimated fluoride intake into low, moderate, and high intake tertiles. The lower tertile cutoffs in this study $(0.037 \mathrm{mg} \mathrm{F} / \mathrm{kg}$ bw/day for age $2-5$ years and $0.023 \mathrm{mg} \mathrm{F} / \mathrm{kg}$ bw/day for ages $5-8$ years) were lower than the bottom end of the optimal fluoride intake range ( $0.05 \mathrm{mg} \mathrm{F} / \mathrm{kg} \mathrm{bw} / \mathrm{day})$. Similarly, the upper cutoffs $(0.052 \mathrm{mg} \mathrm{F} / \mathrm{kg}$ bw/day for age $2-5$ years and $0.036 \mathrm{mg} \mathrm{F} / \mathrm{kg}$ bw/day for age $5-8$ years) were also lower than the upper end of the "optimal" fluoride intake range $(0.07 \mathrm{mg} \mathrm{F} / \mathrm{kg} \mathrm{bw} /$ day). For canines and second molars, the prevalence was less than 10 percent in the lowest fluoride intake tertiles and generally more than 25 percent in the highest intake tertiles. For both first and second premolars, the prevalence in the low and high intake tertiles was approximately 10-15 and 25-40 percent, respectively. Also, there were a few subjects with fluorosis with an estimated daily intake level as low as $0.01 \mathrm{mg} / \mathrm{kg} \mathrm{BW}$, as well as subjects with a 0.11 $\mathrm{mg} / \mathrm{kg} \mathrm{BW}$ intake without fluorosis, indicating differences in susceptibility to dental fluorosis.

Timing of fluoride intake is an important determinant of dental fluorosis $\underline{10}, \underline{11}$. Individual-level variations in timing of tooth development also could contribute to these apparent variations in susceptibility. Dental fluorosis prevalence is positively correlated with the duration of tooth development $\underline{\mathbf{1 7}}, \underline{\mathbf{3 9}}$ and thickness of enamel $\underline{\mathbf{4 0}}$. The average time from initiation to completion of enamel formation is longer for the late-erupting teeth (4.1-4.9 years) than the teeth that erupt earlier in life (3.2-3.6 years) $\underline{\mathbf{4 1}} \underline{\mathbf{4 2}}$. Among the late-erupting teeth, the length of time is longest for first and second premolars (mean 4.9 years for both), then second molars ( 4.3 years), and then canines (4.1 years) $\underline{41} \underline{\mathbf{4 2}}$. Larsen et al. $\underline{17}$ and Rwenyonyi et al. $\underline{43}$ reported that a positive correlation existed between the length of mineralization time and fluorosis prevalence. Among the tooth types examined in this study, the average enamel thickness on the buccal surfaces is the highest in first premolars (1.63 $\mathrm{mm})$, followed by second premolars $(1.48 \mathrm{~mm})$, canines $(1.46 \mathrm{~mm})$, and second molars $(1.39 \mathrm{~mm}) \underline{44}$. Larsen et al. 17 reported that thickness of enamel was positively correlated with fluorosis severity when first molars were excluded from analysis, whereas Rwenyonyi et al. $\underline{\mathbf{4 3}}$ found no relationship between thickness of enamel and fluorosis severity. In this current study, we found that the prevalence of dental fluorosis was the highest among second premolars, followed by first premolars, canines, and second molars. Thus, we did not find consistent relationships between dental fluorosis and average duration of enamel formation or enamel thickness.

In previous analyses from the lowa Fluoride Study, Bhagavatula et al. 11 found that fluoride intakes during the ages 2-8 years period were significantly associated with dental fluorosis risk on late-erupting permanent teeth. Hence, we used fluoride intake information from those years for this analysis. Also, we examined the relationships between fluoride intake during two 3-year age intervals, 2-5 years, and 5-8 years. This was done because Bhagavatula et al. 11 reported stronger associations between fluoride intake in the sixth year of life and dental fluorosis prevalence for many of the late-erupting teeth. Consistent with our previous finding, this analysis shows that an incremental increase in fluoride intake during the ages 5 - to 8 -year interval led to greater 
odds for development of dental fluorosis than increases during the other periods that were examined (Figure 1), even though the estimated mean daily fluoride intake in $\mathrm{mg} / \mathrm{kg} \mathrm{BW}$ declined among participants after age 5.

Overall, our results support findings from previous studies that a dose-response relationship exists between fluoride intake and dental fluorosis. We found that about 20-32 percent of participants had definitive, mostly mild dental fluorosis on 2 or more teeth for at least one of the late-erupting permanent tooth types even when they had fluoride intake at the levels considered to be "optimum." The main source of fluoride intake among the study participants was fluoride from drinking water. Fluoride intake data collection and dental examinations for this study occurred under the previous community water fluoridation guidelines when the optimum fluoride level for drinking water was $0.7-1.2 \mathrm{mg} / \mathrm{L}(0.7-1.2 \mathrm{ppm})$ and most regions in lowa fluoridated at $1.0 \mathrm{mg} / \mathrm{L} \underline{45}$. The recent guidelines published by the United States Department of Health and Human Services 46 recommended that the optimum concentration for community water fluoridation should be $0.7 \mathrm{mg} / \mathrm{L}$, which is expected to lead to a decrease in the amount of fluoride intake and a concomitant decrease in fluorosis prevalence.

\section{Strengths and limitations}

An important strength of this study is its use of longitudinal, period-specific fluoride intake data from multiple sources which is unique to the lowa Fluoride Study. However, the results should be interpreted and generalized keeping in mind the limitations of the study. The lowa Fluoride Study sample was predominantly non-Hispanic white, from high socio-economic families and thus not representative of the general population. Parental responses were checked for reliability, but there was no independent validation of responses using tests such as blood or urinary fluoride levels. Another limitation is that we used a conservative definition for dental fluorosis in this study. Subjects who had only one tooth with definitive fluorosis of a given tooth type were excluded because dental fluorosis is usually symmetric in nature. It is likely that some subjects with fluorosis scored on only one tooth per type had a mild form of fluorosis on the contralateral tooth which was not detected by the fluorosis. This decision could have led to an under-estimation of dental fluorosis prevalence in this population. Also, subjects who had less than two teeth with definitive fluorosis and had at least one tooth with a missing fluorosis score for a particular tooth type were excluded from that analysis. This could have led to an overestimation or under-estimation of fluorosis prevalence. Therefore, we cannot estimate the true fluorosis prevalence in this population. Most fluorosis found in the study was very mild to mild and only four children had moderate or severe dental fluorosis.

In conclusion, our results clearly show that dental fluorosis prevalence is closely related to fluoride intake levels. Although most fluorosis in this study was very mild or mild, we found that almost 30 percent of participants had definitive dental fluorosis (FRI score of 2 or 3 on at least two teeth in at least one of the tooth types examined in the study) at fluoride intake levels considered "optimal." We found that higher fluoride intake during the ages 58-year interval led to greater odds for development of dental fluorosis compared to greater fluoride intake during other age intervals. Some of the late-erupting teeth are esthetically important and our findings can be helpful in future decisions about fluoride recommendations that impact fluoride intake during childhood to preserve the caries preventive benefits of fluoride and reduce the risk of dental fluorosis.

\section{References}

1 Burt BA. The changing patterns of systemic fluoride intake. J Dent Res. 1992; 71( 5): 1228- 37.

2 Pendrys DG, Stamm JW. Relationship of total fluoride intake to beneficial effects and enamel fluorosis. J Dent Res. 1990; 69: 529- 38. discussion 56-7.

3 Kumar JV, Green EL, Wallace W, Carnahan T. Trends in dental fluorosis and dental caries prevalences in Newburgh and Kingston, NY. Am J Public Health. 1989; 79( 5): 565- 9.

4 Beltran-Aguilar ED, Griffin SO, Lockwood SA. Prevalence and trends in enamel fluorosis in the United States from the 1930s to the 1980s. J Am Dent Assoc. 2002; 133( 2): 157- 65.

5 Dean HT, Dixon RM, Cohen C. Mottled enamel in Texas. Public Health Rep. 1935; 50( 13): 424- 42. 
6 McClure FJ, Likins RC. Fluorine in human teeth studied in relation to fluorine in the drinking water. J Dent Res. 1951; 30( 2): 172- 6.

7 Singh KA, Spencer AJ. Relative effects of pre- and post-eruption water fluoride on caries experience by surface type of permanent first molars. Community Dent Oral Epidemiol. 2004; 32( 6): 435- 46.

8 DenBesten PK, Thariani H. Biological mechanisms of fluorosis and level and timing of systemic exposure to fluoride with respect to fluorosis. J Dent Res. 1992; 71( 5): 1238- 43.

9 Hong L, Levy SM, Warren JJ, Broffitt B, Cavanaugh J. Fluoride intake levels in relation to fluorosis development in permanent maxillary central incisors and first molars. Caries Res. 2006; 40( 6): 494- 500.

10 Hong L, Levy SM, Broffitt B, Warren JJ, Kanellis MJ, Wefel JS,Dawson DV. Timing of fluoride intake in relation to development of fluorosis on maxillary central incisors. Community Dent Oral Epidemiol 2006; 34( 4): 299- 309.

11 Bhagavatula P, Levy SM, Broffitt B, Weber-Gasparoni K, Warren JJ. Timing of fluoride intake and dental fluorosis on late-erupting permanent teeth. Community Dent Oral Epidemiol. 2016; 44( 1): 32- 45.

12 Pendrys DG, Katz RV, Morse DE. Risk factors for enamel fluorosis in a fluoridated population. Am J Epidemiol. 1994; 140( 5): 461- 71.

13 Pendrys DG, Katz RV, Morse DE. Risk factors for enamel fluorosis in a nonfluoridated population. Am J Epidemiol. 1996; 143( 8): 808- 15.

14 Ishii T, Suckling G. The severity of dental fluorosis in children exposed to water with a high fluoride content for various periods of time. J Dent Res. 1991; 70( 6): 952- 6.

15 Pendrys DG, Katz RV. Risk of enamel fluorosis associated with fluoride supplementation, infant formula, and fluoride dentifrice use. Am J Epidemiol. 1989; 130( 6): 1199- 208.

16 Kroon J. The relation between toothpaste usage and fluorosis: a cause for concern? SADJ. 2001; 56( 1): $20-7$.

17 Larsen MJ, Kirkegaard E, Poulsen S. Patterns of dental fluorosis in a European country in relation to the fluoride concentration of drinking water. J Dent Res. 1987; 66( 1): 10- 2.

18 Larsen MJ, Richards A, Fejerskov O. Development of dental fluorosis according to age at start of fluoride administration. Caries Res. 1985; 19( 6): 519- 27.

19 Sudhir KM, Suresh S, Prashant GM, Reddy VV, Shafiulla M,Chandu GN. Distribution patterns of enamel fluorosis in permanent dentition. Oral Health Prev Dent. 2012; 10( 2): 167- 74.

20 van Palenstein Helderman WH, Mabelya L, Van't Hof MA, Konig KG. Two types of intraoral distribution of fluorotic enamel. Community Dent Oral Epidemiol. 1997; 25( 3): 251- 5.

21 Manji F, Baelum V, Fejerskov O, Gemert W. Enamel changes in two low-fluoride areas of Kenya. Caries Res. 1986; 20( 4): 371- 80.

22 Baelum V, Fejerskov O, Manji F, Larsen MJ. Daily dose of fluoride and dental fluorosis. Tandlaegebladet. 1987; 91( 10): 452- 6.

23 Ramires I, Pessan JP, Levy FM, Rodrigues MH, de Almeida BS,Kato MT, Peres SH, Buzalaf MA. Prevalence of dental fluorosis in Bauru, São Paulo, Brazil. J Appl Oral Sci. 2007; 15( 2): 140- 3.

24 Levy SM, Kiritsy MC, Slager SL, Warren JJ, Kohout FJ. Patterns of fluoride dentifrice use among infants. Pediatr Dent. 1997; 19( 1): 50- 5.

25 Levy SM, Warren JJ, Davis CS, Kirchner HL, Kanellis MJ, Wefel JS.Patterns of fluoride intake from birth to 36 months. J Public Health Dent. 2001; 61( 2): 70- 7.

26 Levy SM, Warren JJ, Broffitt B. Patterns of fluoride intake from 36 to 72 months of age. J Public Health Dent. 2003; 63( 4): 211- 20.

27 Tai MM. A mathematical model for the determination of total area under glucose tolerance and other metabolic curves. Diab Care.1994; 17( 2): 152- 4.

28 Cruz-Orcutt N, Warren JJ, Broffitt B, Levy SM, Weber-Gasparoni K. Examiner reliability of fluorosis scoring: a comparison of photographic and clinical examination findings. J Public Health Dent.2012; 72( 2): 172- 5.

29 McClure FJ. Ingestion of fluoride and dental caries: quantitative relations based on food and water requirements of children one to twelve years old. Am J Dis Children. 1943; 66( 4): 362- 9. 
30 Maguire A, Zohouri FV, Hindmarch PN, Hatts J, Moynihan PJ.Fluoride intake and urinary excretion in 6- to 7year-old children living in optimally, sub-optimally and non-fluoridated areas. Community Dent Oral Epidemiol. 2007; 35( 6): 479- 88.

31 Levy SM, Eichenberger-Gilmore J, Warren JJ, Letuchy E, Broffitt B,Marshall TA, Burns T, Willing M, Janz $\mathrm{K}$, Torner JC. Associations of fluoride intake with children's bone measures at age 11. Community Dent Oral Epidemiol. 2009; 37( 5): 416- 26.

32 Whitford GM. Fluoride metabolism and excretion in children. J Public Health Dent. 1999; 59( 4): $224-8$.

33 Aasenden R, Peebles TC. Effects of fluoride supplementation from birth on human deciduous and permanent teeth. Arch Oral Biol. 1974; 19( 4): 321- 6.

34 Institute of Medicine (US) Panel on Micronutrients. Dietary reference intakes for vitamin A, vitamin $K$, arsenic, boron, chromium, copper, iodine, iron, manganese, molybdenum, nickel, silicon, vanadium, and zinc. Washington, DC: National Academies Press (US); 2001. [cited 2017 Oct 24]. Available from: https://www.ncbi.nlm.nih.gov/books/NBK222310/

35 Warren JJ, Levy SM, Broffitt B, Cavanaugh JE, Kanellis MJ, Weber-Gasparoni K. Considerations on optimal fluoride intake using dental fluorosis and dental caries outcomes-a longitudinal study. J Public Health Dent. 2009; 69( 2): 111- 5.

36 Pendrys DG. The fluorosis risk index: a method for investigating risk factors. J Public Health Dent. 1990; 50( 5): 291- 8.

37 Slayton RL, Warren JJ, Kanellis MJ, Levy SM, Islam M. Prevalence of enamel hypoplasia and isolated opacities in the primary dentition. Pediatr Dent. 2001; 23(1): 32- 6.

38 Russell AL. The differential diagnosis of fluoride and nonfluoride enamel opacities. J Public Health Dent. 1961; 21( 4): 143- 6.

39 Dean HT, Elvove E. Some epidemiological aspects of chronic endemic dental fluorosis. Am J Public Health Nations Health. 1936; 26( 6): 567- 75.

40 Thylstrup A, Fejerskov O. Clinical appearance of dental fluorosis in permanent teeth in relation to histologic changes. Community Dent Oral Epidemiol. 1978; 6( 6): 315- 28.

41 Nelson SJ. Wheeler's dental anatomy, physiology and occlusion. 9th ed. St. Louis: Saunders Elsevier; 2010.

42 Haavikko $\mathrm{K}$. The formation and the alveolar and clinical eruption of the permanent teeth. An orthopantomographic study. Suom Hammaslaak Toim. 1970; 66( 3): 103- 70.

43 Rwenyonyi CM, Birkeland JM, Haugejorden O, Bjorvatn K. Dental variables associated with differences in severity of fluorosis within the permanent dentition. Clin Oral Investig. 2000; 4( 1): 57- 63.

44 Shillingburg HT, Grace CS. Thickness of enamel and dentin. J South Calif Dent Assoc. 1973; 41( 1): 33- 6 passim.

45 United States Department of Health and Human Services. Fluoridation census, 1992. Atlanta, GA: Department of Health and Human Services, Public Health Service, Centers for Disease Control and Prevention; 1993.

46 United States Department of Health and Human Services. Reports and Recommendations: U.S. Public health service recommendation for fluoride concentration in drinking water for the prevention of dental caries. Public Health Rep. 2015; 130( 4): 318- 31. 